\title{
Acute myeloid leukemia: update in diagnosis and treatment in Brazil
}

\author{
Leucemia mieloide aguda: atualidade brasileira de diagnóstico e tratamento
}

\author{
Ricardo Helman ${ }^{1}$, Fabio Pires de Souza Santos ${ }^{1}$, Belinda Simões ${ }^{2}$, Elias Hallack Atta ${ }^{3}$, Fernando Callera ${ }^{4}$, \\ Jane de Almeida Dobbin ${ }^{5}$, Éderson Roberto Mattos $^{6}$, Angelo Atalla ${ }^{7}$, Angelo Maiolino ${ }^{8}$, Maria Aparecida Zanichelli ${ }^{9}$, \\ Cristiane Fração Diefenbach ${ }^{10}$, Marcia Torresan Delamain ${ }^{11}$, Nelson Hamerschlak ${ }^{1}$
}

\begin{abstract}
Objective: To identify how the Brazilian hematology centers treated and diagnosed cases of acute myeloid leukemia in 2009. Methods: An epidemiological observational multicenter study of 11 listed Brazilian centers that treat acute myeloid leukemia and perform bone marrow transplantation. Data were collected from clinical charts of patients with acute myeloid leukemia treated at the said centers between 2005 and 2009. The availability for immunophenotyping and cytogenetic tests was assessed. Results: During 2009, a total of 345 new cases of acute myeloid leukemia were diagnosed. Differences were noted in the tests performed between patients who initiated treatment at the center and those referred for treatment. Of the participating centers, $72 \%$ conducted some type of molecular study in acute myeloid leukemia upon diagnosis. Conclusion: Treatment for acute myeloid leukemia in Brazil shows significantly inferior results when compared to other centers worldwide.
\end{abstract}

Keywords: Acute myeloid leukemia; Cytogenetic analysis; Molecular diagnostic techniques; Therapeutics; Brazil

\section{RESUMO}

Objetivo: Identificar como centros de hematologia brasileiros trataram e diagnosticaram os casos de leucemia mieloide aguda no ano de 2009. Métodos: Estudo epidemiológico, observacional, multicêntrico de 11 centros brasileiros cadastrados para tratamento de leucemia mieloide aguda e transplante de medula óssea. Os dados foram coletados a partir de prontuários de pacientes com leucemia mieloide aguda tratados nos centros citados entre os anos de 2005 e 2009. Foi avaliada a disponibilidade para realização de exames de imunofenotipagem e citogenética nos centros estudados. Resultados: Foram diagnosticados 345 casos novos de leucemia mieloide aguda no ano de 2009. Observaram-se diferenças na realização de exames entre pacientes que iniciaram o tratamento no centro em relação àqueles referenciados para tratamento. Dos centros participantes, $72 \%$ realizaram algum tipo de pesquisa molecular em leucemia mieloide aguda ao diagnóstico. Conclusão: 0 tratamento da leucemia mieloide aguda no Brasil apresenta resultados muito inferiores quando comparado a outros centros mundiais.

Descritores: Leucemia mieloide aguda; Análise citogenética; Técnicas de diagnóstico molecular; Terapêutica; Brasil

\footnotetext{
Study carried out at Hospital Israelita Albert Einstein - HIAE, São Paulo (SP), Hospital de Clínicas da Faculdade de Medicina de Ribeirão Preto da Universidade de São Paulo - USP, Ribeirão Preto (SP), Instituto Estadual de Hematologia Arthur de Siqueira Cavalcanti - HEMORIO, Rio de Janeiro (RJ), Hospital Pio XII de São José dos Campos - São Jose dos Campos (SP), Instituto Nacional de Câncer INCA, Rio de Janeiro (RJ), Hemocentro da Universidade Estadual de Campinas - UNICAMP - Campinas (SP), Hospital Amaral Carvalho - Jau (SP), Universidade Federal Juiz de Fora - UFJF, Juiz de Fora

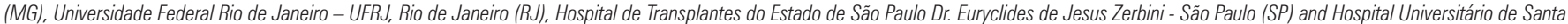
Maria - HUSM, Santa Maria (RS), Brazil.

${ }^{1}$ Hematology and Bone Marrow Transplantation, Hospital Israelita Albert Einstein - HIAE - São Paulo, Brazil.

${ }^{2}$ Hospital das Clínicas, Medical College at Universidade de São Paulo - USP - Ribeirão Preto (SP), Brazil.

${ }^{3}$ Instituto Estadual de Hematologia Arthur de Siqueira Cavalcanti - HEMORIO - Rio de Janeiro (RJ), Brazil.

${ }^{4}$ Hospital Pio XII - São José dos Campos (SP), Brazil.

${ }^{5}$ Instituto Nacional do Câncer - INCA, Rio de Janeiro (RJ), Brazil.

${ }^{6}$ Bone Marrow Transplantation Service of Hospital Amaral Carvalho - Jaú (SP), Brazil.

${ }^{7}$ Universidade Federal de Juiz Fora - UFJF - Juiz de Fora (MG), Brazil

${ }^{8}$ Universidade Federal do Rio de Janeiro - UFRJ, Rio de Janeiro (RJ), Brazil.

${ }^{9}$ Hospital de Transplantes do Estado de São Paulo Dr. Euryclides de Jesus Zerbini - São Paulo (SP), Brazil.

${ }^{10}$ Hospital Universitário de Santa Maria - Santa Maria (RS), Brazil.

${ }^{11}$ Hematology and Hemotherapy Center at Universidade Estadual de Campinas - UNICAMP, Campinas (SP), Brazil.

Corresponding author: Nelson Hamerschlak - Centro de Pesquisa Clínica, Instituto Israelita de Ensino e Pesquisa Albert Einstein - Av. Albert Einstein, 627/701, Piso Chinuch - CEP 05651-901 - São Paulo (SP), Brasil - Tel.: (11) 2151-3203 - e-mail: hamer@einstein.br

Received on: Aug 17, 2010 - Accepted on: Apr 19, 2011

Conflicts of interest: none
} 


\section{INTRODUCTION}

Acute myeloid leukemia (AML) is a malignant neoplasm of progenitor hematopoietic cells and it displays great clinical, morphological, and molecular heterogeneity ${ }^{(1)}$. The classification of AML has been greatly modified over the last decades, and currently, the most often utilized follows cytogenetic and molecular alterations described recently (Table 1$)^{(2)}$.

Table 1. Frequency of molecular mutations investigated upon diagnosis of acute myeloid leukemia

\begin{tabular}{lc}
\hline Mutations & $\%$ \\
\hline FLT3 & 45.45 \\
NPM1 & 18.18 \\
MLL & 36.36 \\
PML/RARa & 81.82 \\
\hline
\end{tabular}

The treatment of a patient with AML begins with the so-called induction chemotherapy, with the objective of controlling the disease and leading the patient into a state of complete remission (CR), in which the disease is no longer detected by conventional morphological methods $^{(3-6)}$. It is common knowledge, however, that reaching the state of $\mathrm{CR}$ is not the equivalent of a cure, and since the 1960s and 1970s, various studies have shown the need to administer post-remission or consolidation therapy ${ }^{(7-9)}$. There are three therapeutic modalities that can be administered to AML patients in post-remission: conventional dose chemotherapy, highdose chemotherapy followed by rescue therapy with autologous hematopoietic stem-cells, and allogenic hematopoietic stem-cell transplant ${ }^{(7-9)}$. The decision as to which therapeutic modality should be used is a result of many studies and essentially depends on the definition of prognostic factors ${ }^{(4)}$.

The determination of prognostic factors is vitally important in AML, since it allows stratification of treatment by means of groups of risk (low, medium, and high-risk).

Classically, stratification of risk groups in patients with AML is guided primarily by cytogenetic alterations $^{(10-14)}$, and could be divided into: (i) favorable prognosis; (ii) intermediate prognosis; and (iii) poor prognosis. Patients with a favorable prognosis (10 to $15 \%)$ include those with $\mathrm{t}(15 ; 17)$ and translocations that involve the core binding factor $(\mathrm{CBF})$ transcription factor, including, in this group, patients with $\mathrm{t}(8 ; 21)$ and with $\operatorname{Inv}(16$.$) Poor prognosis is characterized by patients$ who present with specific cytogenetic alterations, such as deletion and monosomy of chromosomes 5 and 7, besides a complex karyotype ( 3 or more alterations). Finally, the intermediate group, which corresponds to most patients, includes those with normal karyotype (approximately half of them) and those presenting with other cytogenetic abnormalities that do not fit the groups of a good or poor prognosis (Table 2).

Table 2. Induction protocol of acute myeloid leukemia

\begin{tabular}{lc}
\hline Protocol & $\%$ \\
\hline $3+7$ with Idarubicin & 36.36 \\
$3+7$ with Daunorubicin & 63.64 \\
\hline
\end{tabular}

Risk stratification according to cytogenetic criteria caused a strong impact on prognosis, with overall survival and event-free survival well under those of the high-risk group ${ }^{(10,11,13-14)}$. It also enabled adjusting treatment as per the patient's risk. Classically, for highrisk patients, the tendency has been to perform the allogenic hematopoietic stem-cell transplant. As to lowrisk patients, consolidation with Ara-C chemotherapy at high doses in repeated cycles has been sufficient to lead to cure for 50 to $60 \%$ of them. For patients with intermediate risk, however, which corresponds to the majority of AML patients, there is still no definition as to the best therapeutic practice, especially in elderly patients ( $>60$ years of age $)^{(4,7,10)}$.

Today risk classification has become even more complex since several molecular alterations were described and certain molecular alterations (mutations of genes FLT3 and NPM1, for example) subdivide the individuals with intermediate prognosis into those with a good and those with a poor prognosis ${ }^{(15,16)}$. Other mutations, such as point mutations of the C-KIT gene, confer a poor prognosis in AML patients with abnormalities of the CBF gene ${ }^{(17)}$.

This new model of leukemogenesis, combining the activity of a genetic alteration that results in a genetic modification of tyrosine-kinase, such as FLT3, with events that cause a blockage in cellular differentiation, is very appealing not only from the point of view of understanding the pathological process, but also because it has a strong influence on clinical practice and therapeutics. In fact, it has been proposed that mutations of the NPM1 gene define a specific subtype of AML, with specific clinical, molecular, and prognostic characteristics ${ }^{(2)}$. Recently, Schlenk et al. ${ }^{16}$ demonstrated, in a retrospective analysis, that AML patients with a mutation of NPM1 and absence of mutation of FLT3, or who presented with a mutation of CEBPA, had the same survival whether or not they had received an allogenic hematopoietic stem-cell transplant as post-remission therapy. On the other hand, patients with a FLT3 mutation or who were negative for all mutations (CEBPA, NPM1, and FLT3) presented with an lower survival if they had not received an allogenic hematopoietic stem-cell transplant ${ }^{(18,19)}$. In light of 
these advances, a group of AML experts has recently proposed a risk classification integrating cytogenetic and molecular abnormalities ${ }^{(4)}$.

\section{OBJECTIVE}

Based on this scenario, the present study was proposed to evaluate the Brazilian situation regarding available tests for diagnosis as well as treatment protocols used in the main AML treatment centers in Brazil.

\section{METHODS}

An epidemiological, observational, multicenter study was conducted of 11 centers enrolled in Brazil for the treatment of AML and bone marrow transplants. The participating centers were Hospital Israelita Albert Einstein (HIAE), Hospital de Clínicas da Faculdade de Medicina de Ribeirão Preto da Universidade de São Paulo (HCFMRP/USP), Instituto Estadual de Hematologia Arthur de Siqueira Cavalcanti (HEMORIO), Hospital Pio XII de São José dos Campos, Instituto Nacional de Câncer (INCA), Hemocentro da Universidade Estadual de Campinas (UNICAMP), Hospital Amaral Carvalho, Universidade Federal Juiz de Fora (UFJF), Universidade Federal Rio de Janeiro (UFRJ), Hospital de Transplantes do Estado de São Paulo Dr. Euryclides de Jesus Zerbini, and Hospital Universitário de Santa Maria (HUSM).

The study was retrospective, with a collection of data from the clinical records of AML patients treated at the cited centers between 2005 and 2009. The following data were analyzed: availability for performance of immunophenotyping, cytogenetics by simple karyotype or FISH for genes PML-RARA, AML1-ETO, CBFBMYH11, and molecular mutation investigation (FLT3, NPM1, KIT).

As to the treatment of promyelocytic leukemia, the study included patients treated as per the Brazilian protocol or another induction regimen.

Patients were assessed relative to induction protocols they received and the consolidation regimen used as per their risk.

\section{RESULTS}

Of the sum of all patients from the participating centers, 345 new cases of AML were diagnosed in 2009. As to diagnostic tests performed at the treatment centers, it was noted that $90.9 \%$ of the transplant centers carried out immunophenotyping and band karyotyping when patients were treated at the center from the beginning; however, when the patients had been referred for consolidation treatment with bone marrow transplantation, only 51.2\% of the centers conducted immunophenotyping and $42.73 \%$ determined the karyotype upon diagnosis. Of the participating centers, $72 \%$ performed some type of molecular research of AML upon diagnosis.

The rates of molecular mutations that most frequently correlated with the prognosis in AML are described on Table 1. In the assessment of induction schemes used for treatment of AML, all centers used the classic regimen, with anthracycline and cytarabine at low doses and continuous infusion for 7 days (Table 2). Several consolidation regimens were used (Table 3). Most treatment centers used two cycles of high doses of cytarabine for consolidation of AML (45.4\%), and $27.3 \%$ of the centers used three cycles, while $9.0 \%$ of the centers used more than four chemotherapy cycles.

Table 3. Consolidation regimen used in the treatment centers

\begin{tabular}{lccc}
\hline Risk/treatment & $\begin{array}{c}\text { High doses } \\
\text { cytarabine } \\
\%\end{array}$ & $\begin{array}{c}\text { Autologous } \\
\text { BMT } \\
\%\end{array}$ & $\begin{array}{c}\text { Allogenic } \\
\text { BMT } \\
\%\end{array}$ \\
\hline Low & 72.73 & 27.27 & Zero \\
Intermediate & Zero & 9.09 & $81.82^{*}$ \\
High & Zero & Zero & $100^{*}$ \\
\hline
\end{tabular}

*If compatible donor.

BMT: bone marrow transplant.

Treatment of promyelocytic leukemia at the participating centers was performed with the ATRA (transretinoic acid) and anthracycline $(90.75 \%)$ regimen, and the majority was included in the Brazilian Protocol for Treatment of Promyelocytic Leukemia (54.5\%).

\section{DISCUSSION}

Information on the pathophysiology of AML has evolved significantly over the last years, primarily due to new discoveries of the genetics of diseased cells and its molecular implications. This new knowledge has also led to the new classification of AML by the World Health Organization (WHO), with the creation of an AML group with recurring cytogenetic alteration ${ }^{(20)}$. With this new classification, the performance of the simple cytogenetic test upon diagnosis of new cases of AML is mandatory, in order to guide therapeutic practice. In Brazil, is it noted that in reference bone marrow centers for treatment of AML, only $42 \%$ of patients underwent cytogenetic testing - a very low number if compared to centers from developed countries. The absence of karyotyping at diagnosis leads especially to the impossibility of correctly stratifying the patient's risk, and therefore, to treatment decisions that may not be the most appropriate ${ }^{(21)}$.

As to tests regarding molecular mutations of genes FLT3, NPM1, and KIT, although its role in risk 
stratification of AML is well established in literature, its performance is still not obligatory as per WHO and by the primary AML treatment protocols - but merely within clinical trials. The low incidence of performance of these tests in Brazil, however, is a matter of concern, since these mutations will soon enter the roll of fundamental tests for therapeutic decisions, such as in the indication of first-line allogenic bone-marrow transplant ${ }^{(22)}$. The high cost of implementing molecular biology testing, as well as the lack of trained personnel to conduct these tests, which involve real-time RNA- and PCR extraction methodology are the primary limiting factors for its routine diagnostic performance. Despite the surprising number of centers that do perform some form of AML molecular research (72\%), most only carry out investigation of the PML-RARA gene mutation of promyelocytic leukemia. This fact is due primarily to the importance of this mutation for the diagnosis of this entity that displays a more favorable clinical course and has a specific induction regimen ${ }^{(23)}$.

In the present study, it was possible to perceive that the treatment of AML in Brazil follows the main protocols employed around the world, where the choice treatment of all participating centers was made by induction with the classic protocol of seven days of continuous infusion of cytarabine and three days of anthracycline, whether daunorubicin or idarubicin. In analyzing the induction protocols used in Brazil, the lack of these and of national multicenter studies is noteworthy, since only the Brazilian Protocol for Treatment of Promyelocytic Leukemia was cited for inclusion of patients. In a country of continental dimensions such as Brazil, with possibilities of becoming a reference in AML treatment, the implementation of new multicenter studies in AML treatment is imperative, with an emphasis on new diagnostic methods.

When the AML consolidation regimens used in Brazil are analyzed, it is clear that allogenic bone marrow transplantation is the primary choice for patients with a compatible donor in the family. This indication is based, above all, on the presence of cytogenetic alterations.

\section{CONCLUSION}

The treatment of AML in Brazil shows results that are very inferior when compared to those of other world centers. The lack of information for adequate stratification of risk of patients, such as bands cytogenetics and investigation of molecular mutations, is the chief cause of failure in AML treatment in Brazil.

Investment in the area of diagnosis is paramount for improving treatment of AML in Brazil.

\section{REFERENCES}

1. Gilliland DG, Jordan CT, Felix CA. The molecular basis of leukemia. Hematology Am Soc Hematol Educ Program. 2004:80-97.

2. Swerdlow SH, Campo E, Harris NL, Jaffe ES, Pileri SA, Stein H, et al. World Health Organization Classification of Tumours of Haematopoietic and Lymphoid Tissues. 4th ed. Lyon: IARC Press; 2008.

3. Hann IM, Stevens RF, Goldstone AH, Rees JK, Wheatley K, Gray RG, et al. Randomized comparison of DAT versus ADE as induction chemotherapy in children and younger adults with acute myeloid leukemia. Results of the Medical Research Councils 10th AML trial (MRC AML10). Adult and Childhood Leukaemia Working Parties of the Medical Research Council. Blood. 1997;89(7):2311-8.

4. Döhner H, Estey EH, Amadori S, Appelbaum FR, Büchner T, Burnett AK, Dombret H, Fenaux P, Grimwade D, Larson RA, Lo-Coco F, Naoe T, Niederwieser D, Ossenkoppele GJ, Sanz MA, Sierra J, Tallman MS, Löwenberg B, Bloomfield CD; European LeukemiaNet. Diagnosis and management of acute myeloid leukemia in adults: recommendations from an international expert panel, on behalf of the European Leukemia Net. Blood. 115(3):453-74.

5. Cheson BD, Bennett JM, Kopecky KJ, Büchner T, Willman CL, Estey EH, Schiffer CA, Doehner H, Tallman MS, Lister TA, Lo-Coco F, Willemze R, Biondi A, Hiddemann W, Larson RA, Löwenberg B, Sanz MA, Head DR, Ohno R, Bloomfield CD; International Working Group for Diagnosis, Standardization of Response Criteria, Treatment Outcomes, and Reporting Standards for Therapeutic Trials in Acute Myeloid Leukemia. Revised recommendations of the International Working Group for Diagnosis, Standardization of Response Criteria, Treatment Outcomes, and Reporting Standards for Therapeutic Trials in Acute Myeloid Leukemia. J Clin Oncol. 2003;21(24):4642-9.

6. Estey E. Response in acute myeloid leukemia. Clin Adv Hematol Oncol. 2008;6(2):113-7.

7. Koreth J, Schlenk R, Kopecky KJ, Honda S, Sierra J, Djulbegovic BJ, et al. Allogeneic stem cell transplantation for acute myeloid leukemia in first complete remission: systematic review and meta-analysis of prospective clinical trials. JAMA. 2009;301(22):2349-61.

8. Breems DA, Löwenberg B. Acute myeloid leukemia and the position of autologous stem cell transplantation. Semin Hematol. 2007:44(4):259-266.

9. Mayer RJ, Davis RB, Schiffer CA, Berg DT, Powell BL, Schulman P, et al. Intensive post-remission chemotherapy in adults with acute myeloid leukemia. Cancer and Leukemia Group B. N Engl J Med. 1994;331(14):896-903.

10. Grimwade D, Walker H, Oliver F, Wheatley K, Harrison C, Harrison G, et al. The importance of diagnostic cytogenetics on outcome in AML: analysis of 1,612 patients entered into the MRC AML 10 trial. The Medical Research Council Adult and Childrens Leukaemia Working Parties. Blood. 1998;92(7):2322-33.

11. Schoch C, Kern W, Schnittger S, Büchner T, Hiddemann W, Haferlach T. The influence of age on prognosis of de novo acute myeloid leukemia differs according to cytogenetic subgroups. Haematologica. 2004;89(9):1082-90.

12. Schoch C, Kern W, Schnittger S, Hiddemann W, Haferlach T. Karyotype is an independent prognostic parameter in therapy-related acute myeloid leukemia (t-AML): an analysis of 93 patients with t-AML in comparison to 1091 patients with de novo AML. Leukemia. 2004;18(1):120-5.

13. Slovak ML, Kopecky KJ, Cassileth PA, Harrington DH, Theil KS, Mohamed A, et al. Karyotypic analysis predicts outcome of pre-remission and post-remission therapy in adult acute myeloid leukemia: a Southwest Oncology Group/Eastern Cooperative Oncology Group Study. Blood. 2000;96(13):4075-83.

14. Byrd JC, Mrózek K, Dodge RK, Carroll AJ, Edwards CG, Arthur DC, Pettenati MJ, Patil SR, Rao KW, Watson MS, Koduru PR, Moore JO, Stone RM, Mayer RJ, Feldman EJ, Davey FR, Schiffer CA, Larson RA, Bloomfield CD; Cancer and Leukemia Group B (CALGB 8461). Pretreatment cytogenetic abnormalities are predictive of induction success, cumulative incidence of relapse, and overall survival in adult patients with de novo acute myeloid leukemia: results from Cancer and Leukemia Group B (CALGB 8461). Blood. 2002;100(13):4325-36.

15. Schlenk RF, Döhner K. Impact of new prognostic markers in treatment decisions in acute myeloid leukemia. Curr Opin Hematol. 2009;16(2):98-104. 
16. Schlenk RF, Döhner K, Krauter J, Fröhling S, Corbacioglu A, Bullinger L, Habdank M, Späth D, Morgan M, Benner A, Schlegelberger B, Heil G, Ganser A, Döhner $\mathrm{H}$; German-Austrian Acute Myeloid Leukemia Study Group. Mutations and treatment outcome in cytogenetically normal acute myeloid leukemia. N Engl J Med. 2008;358(18):1909-18.

17. Paschka P, Marcucci G, Ruppert AS, Mrózek K, Chen H, Kittles RA, Vukosavljevic T, Perrotti D, Vardiman JW, Carroll AJ, Kolitz JE, Larson RA, Bloomfield CD; Cancer and Leukemia Group B. Adverse prognostic significance of KIT mutations in adult acute myeloid leukemia with inv(16) and t(8;21): a Cancer and Leukemia Group B Study. J Clin Oncol. 2006;24(24):3904-11.

18. Chan WI, Huntly BJ. Leukemia stem cells in acute myeloid leukemia. Semin Oncol. 2008;35(4):326-35.
19. Huntly BJ, Shigematsu H, Deguchi K, Lee BH, Mizuno S, Duclos N, et al. MOZTIF2, but not BCR-ABL, confers properties of leukemic stem cells to committed murine hematopoietic progenitors. Cancer Cell. 2004;6(6):587-5.

20. Vardiman JW,Harris NL, Brunning RD. The World Health Organization (WHO) classification of the myeloid neoplasms. Blood. 2002;100(7):2292-302.

21. Pelloso LAF, Chauffaille MLF, Ghaname FS, Yamamoto M, Bahia DMM, Kerbauy J. Cariótipo em leucemia mielóide aguda: importância e tipo de alteração em 30 pacientes ao diagnóstico. Rev Assoc Med Bras. 2003;49(2):150-5

22. Stone RM. Prognostic factors in AML in relation to (ab)normal karyotype. Best Pract Res Clin Haematol. 2009;22(4):523-8.

23. Ravandi F. Therapy-related acute promyelocytic leukemia. Haematologica. 2011:96(4):493-5. 